This item was submitted to Loughborough's Research Repository by the author.

Items in Figshare are protected by copyright, with all rights reserved, unless otherwise indicated.

\title{
Popularity and proliferation: Shifting modes of authorship in Mary Elizabeth Braddon's The Doctor's Wife and Vixen
}

PLEASE CITE THE PUBLISHED VERSION

http://dx.doi.org/10.1080/09699082.2015.1130284

\section{PUBLISHER}

(CTaylor \& Francis (Routledge)

\section{VERSION}

AM (Accepted Manuscript)

\section{PUBLISHER STATEMENT}

This work is made available according to the conditions of the Creative Commons Attribution-NonCommercialNoDerivatives 4.0 International (CC BY-NC-ND 4.0) licence. Full details of this licence are available at: https://creativecommons.org/licenses/by-nc-nd/4.0/

\section{LICENCE}

CC BY-NC-ND 4.0

\section{REPOSITORY RECORD}

Beller, Anne-Marie. 2016. "Popularity and Proliferation: Shifting Modes of Authorship in Mary Elizabeth Braddon's the Doctor's Wife and Vixen”. Loughborough University. https://hdl.handle.net/2134/22581. 
ANNE-MARIE BELLER

POPULARITY AND PROLIFERATION: SHIFTING MODES OF AUTHORSHIP IN MARY ELIZABETH BRADDON'S THE DOCTOR'S WIFE (1864) AND VIXEN (1879)

\begin{abstract}
Mary Elizabeth Braddon's long career coincided with a shift in writing practices, as the Victorian literary marketplace became increasingly professionalized and competitive. This article argues that Braddon intervened in contemporary debates about the status of the popular novelist and the nature of authorship through her fiction, implicitly mounting a defence against the critical attacks on her own prolific production. Through a discussion of representations of authorship in The Doctor's Wife (1864) and Vixen (1879), it is suggested that Braddon offers an important example of a bestselling female novelist who both exemplified the changing construction of composition in the nineteenth century and the move towards mass culture, and also engaged with and commented on this transition in interesting ways.
\end{abstract}

Mary Elizabeth Braddon was indisputably the queen of the mid-Victorian literary marketplace. Following the phenomenal success of Lady Audley's Secret in 1862, each of Braddon's subsequent novels of the 1860s achieved impressive sales figures, running through numerous editions in swift succession, and for decades her name was a byword for all that was lauded and loathed about the female "sensation novelist". ${ }^{1}$ Braddon epitomised the extraordinary productivity of the Victorian popular writer and, in doing so, helped to fuel contemporary anxieties about the transition towards mass-production, the commodification of culture, and large, discrete readerships. ${ }^{2}$ This association with a shifting mode of literary production and consumption significantly affected Braddon's critical reputation, in her own lifetime and beyond. In 1911, as she was approaching the end of her long and prolific career, fellow novelist and friend, Lucy Clifford, pointed out what she saw as Braddon's greatest mistake as a writer:

Your stories are all admirable, but you have written too many — or rather ... you have put your name on too many. You might have had three reputations ... People can't believe your work can all be on its highest level ... because there is so much of it, so many good books, that they think it impossible that anyone could do so much that is $\operatorname{good} .$. [emphases in original] ${ }^{3}$

At over eighty novels, if one includes the early anonymous serials, in addition to short stories, plays, and poetry, Braddon's extraordinary productivity was a key factor in the public construction of her as a commercially-driven writer striving only for "popular" success. Consequently, her positioning within the literary marketplace, as well as her critical reputation, was shaped, in large part, by the perception that she simply wrote too much. The issue of Braddon's productivity also fed in to wider debates of the mid-nineteenth century about the status of authorship and the nature of composition.

The decade in which Braddon began her writing career was an important juncture in the critical perception and treatment of literature, particularly the novel. ${ }^{4}$ It was a period of unprecedented expansion in the area of publishing, which saw a significant growth in the 
number of new journals, many of them devoting considerable space to serialised fiction. The period also saw an opening up of the literary marketplace for women, many of whom began to conduct their own periodicals in the 1860 s. $^{5}$ This extension of opportunities for women in fiction and journalism, together with an increasingly democratised reading public, were key elements in the move towards a widening distinction between the popular and the serious, between "entertainment" and "art". 6 In many ways, this period can be seen as the beginning of the "culture split", which was consolidated by the Modernist movement in the early twentieth century, and for those cultural commentators intent on protecting the exclusivity and aesthetic value of literature, prolific popular writers like Braddon provided an obvious scapegoat. In an 1865 review of Braddon's Sir Jasper's Tenant, G. H. Lewes commented on the recent "vast increase in novels", which he claimed posed "a serious danger to public culture". ${ }^{7}$ Lewes's assumption throughout his essay, that proliferation is of necessity synonymous with trivial and second-rate, typified an increasingly common belief among the critical establishment of the mid-Victorian period, which of course encoded anxieties about the transformation of literary modes of production, the commodification of literature, and the concomitant threat to its aesthetic value.

As a woman writer embarking on her career at the beginning of the 1860s, Braddon both profited and suffered by the evolving constructions of literary authorship that were in progress. In 1862 she observed that "It has been my good, or bad, fortune to be flung into a very rapid market, \& to have every thing printed $\&$ published almost before the ink with which it was written was dry". 8 The uncertainty about whether this is "good" or "bad" fortune reflects Braddon's personal conflict regarding the type of novelist she wished to be: as she confessed to her mentor, Edward Bulwer Lytton, "I am always divided between a noble desire to attain something like excellence - and a very ignoble wish to earn plenty of money". ${ }^{9}$ In some senses, Braddon was not alone in experiencing this kind of conflict. With the move towards the professionalization of authorship, perplexing ambiguities emerged concerning the legitimacy of literature which, for some, was unavoidably tainted by its proximity to more alienated forms of labour. Was "literary labour" a profession or a trade? Even those authors who actively sought to promote the cultural validity and prestige of the novel occasionally expressed resentment that their efforts should be so poorly rewarded in financial terms, in comparison to popular writers such as Braddon. George Eliot, for example, famously claimed that the novelist who looks primarily to the potential sales and profit of his work and cares only for writing what will sell "carries on authorship on the principle of the gin-palace. And bad literature of the sort called amusing is spiritual gin". 10 At the same time, though, Eliot admits that it is entirely proper for an author to seek appropriate remuneration for his or her work, but in turn he or she is honour-bound to produce a quality product, which should not be rushed and should not repeat previous work: "An author who would keep a pure and noble conscience, and with that a developing instead of degenerating intellect and taste, must cast out of his aims the aim to be rich". "For Eliot, and for many others, Braddon was guilty of all these crimes - in her commercial drive, her occasional plagiarisms made scandalously public during the late $1860 \mathrm{~s}$, her prolific output, and her quest for popularity. ${ }^{12}$

Braddon's own admission, in a letter to Bulwer, that she rushed off the last volume of Lady Audley's Secret and part of the second "in less than a fortnight", with "the printer at [her] all the time"13 would seem to confirm the complaints that Eliot levels at popular novelists. If the account of rushing to meet deadlines in one sense aligns Braddon's methods of composition with the professional, businesslike model of authorship that had emerged with Dickens's transformation of the literary marketplace, it also, more damagingly, implicitly associates Braddon with the "damned mob of scribbling women" evoked by Hawthorne. Given prevailing assumptions about female dependency and the undesirability of women 
obtruding themselves into financial concerns, what might be deemed shrewd and professional business sense in a male author was far less commendable in a woman writer, who remained subject to debilitating stereotypes of respectable feminine behaviour.

Braddon's prolific output, and the "mechanical" rapidity with which she was perceived to compose her novels, played on fears that, despite sustained attempts by male and female authors from the 1840s onwards to construct authorship as a professional, middle-class occupation, the nature of producing books in the increasingly commercialized Victorian literary marketplace remained closely associated with (if not contaminated by) more working-class modes of production. ${ }^{14}$ As Linda Peterson points out, "Many nineteenthcentury writers $[\ldots]$ feared the taint of trade because they sold manuscripts to publishers and thus, perhaps, dealt in commodities: books, pamphlets, articles." 15 This is clearly evident in the language of manufacture and trade that repeatedly emerges in literary criticism of the period and in criticism of Braddon in particular. As early as 1822, Walter Scott had declared that: "a successful author is a productive labourer, and his works constitute as effectual a part of the public wealth as that which is created by any other manufacture" [emphasis added]. ${ }^{16}$ Here the language of industry and economics is employed in a positive sense, but in the increasingly commercial and aggressively competitive world of 1860s publishing, such imagery had become distinctly problematic. The critical reception of Braddon's fiction persistently conflates her methods of composition with the lower-class occupations of trade and industrial manufacture as a means of devaluing the legitimacy of her work. A reviewer for the Morning Post declared of Braddon's 1865 novel, Sir Jasper's Tenant that: "The process by which a novelist becomes converted into a novel-producing machine is clearly traceable in the progress of Miss Braddon's latest work"17, an image which subordinates any sense of human creativity by reducing the author function to a mindless and mechanical practice. Nearly thirty years later, The Times echoed this representation of Braddon's mechanized methods of composition, claiming that she "puts forth novels with the regularity and precision of a machine." 18

Such judgments, which are representative of a much larger sample, underline an integral paradox in the endeavour to professionalize Victorian authorship, yet simultaneously retain traditional aesthetic values. For the insistent associations of Braddon with machinery point to the possibility that the professional author's mode of production might be transformed into a mimicry of the very technologies which made the profession of authorship a viable proposition in the first place. Henry Mansel's objection to sensation novels, that "a commercial atmosphere hangs around works of this class, redolent of the manufactory or the shop" 19 is another typical example of the way in which critics were increasingly distinguishing between two distinct types of fiction: one which contributed to an Arnoldian ideal of "sweetness and light", and the other, merely a debased and mechanical form of mass entertainment, offering no form of intellectual or moral benefit. This distinction was an essential strategy for enabling a construction of middle-class professional authorship that did not compromise class status or cultural prestige.

Intrinsically linked to the critics' censure of Braddon's prolific output were speculations about the speed and rapidity of her composition. The Morning Post reviewer, cited above, expresses genuine admiration in parts of his critique of her work, but regrets that Braddon publishes too much and thereby sacrifices quality to quantity:

Does she recognise that haste, and carelessness, that her ill-judged yielding to the fatal temptation to over-work, to undertaking too many things at once; that the lowering of her own estimate of the dignity of literature, apart from its commercial and social 
value, have induced her to spoil the best picture she has yet penned? She is not a solitary instance of this unhappy "high pressure" infatuation, but she is so remarkable an instance of it that she must expect to be regarded as almost its type. ${ }^{20}$

The reference to the "high pressure" infatuation locates Braddon's novel-writing process within a broader experience of modernity with its significantly accelerated pace of life. As Nicholas Daly has demonstrated, sensation novels, including those of Braddon, functioned as a kind of "training" in modernity for readers, by using their sensational techniques of shock and suspense to acclimatize readers to the new fast-paced, industrialized, urban experience. ${ }^{21}$ What is less frequently discussed is the way in which that fast-paced, industrialised experience and the transformed conditions of literary production it engendered, also impacted on writers' methods of working in very tangible ways. As Braddon complained in a letter of 1862, "I have never written a line that has not been written against time.",22

If critics generally were disparaging of such indecent haste, some were also seemingly fascinated by Braddon's ability to produce novel after novel, sometimes two or more simultaneously. Many affected amazement tinged with derision, such as the reviewer who commented: "We do not often, from choice, read one of Miss Braddon's novels. Indeed, they issue so fast from her hand ... that it is hard for the most diligent reviewer to keep with them" ${ }^{, 23}$. But others displayed a genuine interest in the logistics involved in such rapid composition. The New York Times in 1897 observed: "Miss Braddon puts her novels on paper at the rate of 1,500 words an hour. Now, that is speed which, while not by any means impossible, is certainly remarkable." The writer goes on to make a significant comparison: "Reporters not infrequently exceed [...] the limits mentioned, but they are recorders rather than creators, and have only to set down on paper facts well in mind." ${ }^{24}$ Yet the distinction between journalistic recording and literary creation was an unstable boundary in the mid- to late-Victorian period; and, as Richard Salmon has noted, this "proximity" to "more ephemeral forms" was problematic for those writers dedicated to promoting the "cultural prestige" of the novel. ${ }^{25}$

Constantly denigrated by critics for writing too much, too fast, Braddon sought to address these issues in her fiction through a self-reflexive engagement with the nature of composition in the modern literary marketplace. In the following sections I consider examples of Braddon's interventions in contemporary literary debates within two of her novels and suggest that she maps a changing model of authorship, while implicitly mounting a defence against the attacks on her own prolific output. In the first section, I examine the contestation of different modes of literary production in Braddon's first attempt at a non-sensational novel, The Doctor's Wife (1864), focusing specifically on her representations of authorship through the characters Sigismund Smith and Roland Lansdell. I then move on to consider Braddon's satirical treatment of the aspiring "woman of letters" in Vixen (1879), which reinforces her critique of literary pretention and dilettantism in The Doctor's Wife and implicitly endorses her own methods of literary composition.

\section{Composition in Transition in The Doctor's Wife}

Braddon wrote The Doctor's Wife at a key point in the formation of her reputation as a bestselling sensation novelist. In the two years since the success of Lady Audley's Secret, the critical backlash against sensation fiction had escalated to a point of near hysteria in some quarters, and Braddon had become the most frequent target of censure, due in large part to her extraordinary productivity and her phenomenal popularity. As Margaret Oliphant commented in 1867, "Miss Braddon is the leader of her school, [...] but her disciples are 
many". ${ }^{26}$ In The Doctor's Wife, her first self-conscious attempt to escape the sensation label, Braddon supplements the main plot about the eponymous Isabel Sleaford's emotional and psychological development with a quasi-metafictive musing on the changing nature of literary production. A number of recent scholars have noted the self-reflexive function of Sigismund Smith, the hack writer of sensational penny fiction in The Doctor's Wife. He has typically been viewed as a vehicle for his creator's own views on literary production and the type of fiction that she, like Smith, is engaged in writing. Smith follows Braddon's own career trajectory in progressing from penny fiction to the three-volume novel, and he nurses an ambition to one day write a "great novel". For Lyn Pykett "Smith is Braddon's fictional alter ego" and for Robert Lee Wolff, Smith "serves as her own mouthpiece"27. Yet what is usually overlooked in discussions of this novel (which tend to focus on its discourse on reading and readers) is the way in which it also implicitly contrasts two very different ideologies of literary composition through an inferred comparison between Smith, the sensation novelist, and Roland Lansdell, the Byronic hero.

Roland Lansdell is consistently associated with Byron and, by implication, can be seen as a figure for the popular conception of the Romantic poet. Lansdell, the narrator informs us early in the novel, was "wandering somewhere in Greece, upon a Byronic kind of tour that had lasted upwards of six months, and was likely to last much longer." ${ }^{28}$ The Romantic (and romanticized) image of the isolated artist, moved to spontaneous creativity through emotion and inspiration held sway in the Victorian popular imagination, and Braddon evokes these associations (and undermines them) in her depiction of Roland Lansdell. Lansdell is described as an "aristocratic scribbler", whose "Byronic" volume of poetry (entitled "An Alien's Dreams") has made "quite a little sensation". ${ }^{29}$ When the impressionable and dreamy heroine, Isabel, finally meets this "Being", of whom she has previously heard so much, he seems to embody every hero she has worshipped in the novels and poetry which fill her days. For Isabel, Lansdell is "a real poet, a real, living, breathing poet, who only wanted to lame himself, and turn his collars down, to become a Byron." ${ }^{30}$ This contrasts with Sigismund Smith's homely appearance and personality, which is invariably a disappointment to those admirers of his exciting fiction who have been curious to see the author in person: "was this meek young man the Byronic hero they had pictured?"31 Both men's relationship to the construction of the Romantic poet work to situate them within contrasting modes of literary production. Lansdell may outwardly embody Isabel's romanticized, and arguably outmoded, ideal of what a writer should be, but Smith actually earns his living through literature, and every aspect of his conversation, views on fiction, and working habits position Smith firmly within the modern, bustling world of mid-nineteenth century publishing.

The ways in which Smith talks about his working methods echo the language of industry and manufacture discussed previously. He refers to his "day's hard labour" and, in contrast to Lansdell's privately printed, limited edition of poetry, Smith has "produced more sheets of that mysterious stuff which literary people call 'copy' than any other author of his age" (12). ${ }^{32}$ The productivity and industry of the popular novelist are constantly emphasised in Braddon's narrative, and implicitly valued over aristocratic dilettantism. In an episode that echoes the reviewers' comments about Braddon's own speed of composition, one character observes Smith at work: his "rapid pen scratched along the paper in a breathless way, which indicated a dashing and Dumas-like style of literature, rather than the polished composition of a Johnson or an Addison" (12). Similarly, the pressured industry within which Smith is working, signalled in this passage by the printer's boy, who rushes off with Smith's "copy" while "the manuscript is still damp", also recall the comments made by Braddon regarding her own haste to meet deadlines. ${ }^{33}$ 
Lyn Pykett has suggested that "Sigismund's is a form of alienated literary production". 34 Admittedly, the descriptions of Smith's literary activity often evoke a mechanistic quality and he possesses little in the way of cultural capital. Landsell's privately produced book of poetry has achieved a modest success in critical quarters, with a complimentary review in the Westminster, whereas Smith's popular serials are unknown to the high-culture quarterlies and he has "never known what it was to be bound" in volume form $(130 ; 11)$. To some extent then, Pykett's claim is accurate, and Braddon certainly does not idealize either the working methods or the lot of the popular writer. However, she champions Scott's opinion that "a successful author is a productive labourer" and, in doing so, validates her own prolific production and popular status. Smith does indeed go on to achieve his dream of becoming the author of three-volume novels in a later Braddon novel, The Lady's Mile (1866). In keeping with Lansdell's function in the novel generally, where his idleness and lack of a purposeful role in life lead to disastrous consequences for all of the major characters, the aristocratic, pre-eminently Romantic mode of composition with which he is associated is demonstrated ultimately to be unproductive, both socially and commercially. One character comments:

And to think Roland Lansdell should waste his time in writing this sort of thing! And here's his letter, poor boy ... in which he tells me how he wrote the verses, and how writing them was a kind of consolation to him, - a safety-valve for so much passionate anger against a world that doesn't exactly harmonise with the Utopian fancies of a young man with fifteen thousand a-year and nothing to do. ${ }^{35}$

Both modes of writing are associated with a form of catharsis on the part of the author. Yet, whereas Lansdell's composition is supposedly fuelled by genuine feeling and emotional outpouring (the sincerity of which is undermined by the final sentence here), Smith conversely derives vicarious fulfilment through the entirely imaginative doings of his characters. He tells Isabel: "since I've taken to writing novels, I don't think I've a desire unsatisfied. There's nothing I haven't done — on paper". ${ }^{36}$ The narrative trajectory of the novel ultimately demonstrates Smith's displaced methods of fulfilling his desires to be eminently preferable to Lansdell's destructive pursuit of his own selfish impulses, for while Smith has "exhausted all that was passionate in his nature in penny numbers, and has nothing left for the affairs of real life" (p.13), Lansdell's lack of useful occupation, beyond the composition of his "half-heartbroken, half-cynical verses" (120), leads him to conduct a clandestine relationship with Isabel Gilbert, which besmirches her reputation and ends in tragedy for all concerned. Though the attraction of Romantic writing is never denied (hardly surprising in the work of a woman whose favourite poets included Byron and Shelley), Braddon's novel embraces a typically Victorian Protestant work ethic, which advocates steady workmanship over the supposed Romantic model of instinctive, spontaneous, inspiration-led creativity.

Lansdell is killed at the end of the novel by Isabel's criminal father, Mr. Sleaford, also known as "Jack the Scribe", whose occupation of forgery might be seen as a subverted or illegitimate type of authorship. Sleaford's fatal proclivity for signing other people's names, however, seems only marginally removed from Smith's cheerful admissions of plagiarism. As Smith explains to his friend George Gilbert: "when you're doing four great stories a week for a public that must have a continuous flow of incident, you can't be quite as original as a strict sense of honour might prompt you to be; and the next best thing you can do if you haven't got ideas of your own, is to steal other people's ideas in an impartial manner". ${ }^{37}$ Smith calls the results of this literary larceny a "combination novel", a term which might 
aptly be used to describe Braddon's own methods in some of her early work. ${ }^{38}$ If, then, the forger, Jack the Scribe, is symbolically linked to the successful popular novelist Smith (and also to his creator Braddon) through this motif of plagiarism, it is arguably suggestive that Lansdell meets his death at the hands of this character. In the symbolic discourse on authorship in The Doctor's Wife, older (more idealistic) modes are superseded by newer, perhaps less honourable, models of literary production. Lansdell is a recurring type in Braddon's fiction; other examples include Oswald Pentreath in Joshua Haggard's Daughter, Angus Hamleigh in Mount Royal, and Brandon Mountford in Thou Art the Man, all of whom are associated, to varying degrees, with literary Romanticism. They all, without exception, die. While this is not to suggest an oversimplified symbolic re-enactment of the death of the Romantic poet throughout the pages of Braddon's work, it is fair to say that such figures, in their close alignment with what Jerome McGann has termed the "Romantic Ideology", are implicitly related to a model of authorship which Braddon's narratives depict as obsolete in the modern commercial literary market. ${ }^{39}$

\section{"He doesn't care for poetry. He likes Byron"40: Satirising the high-brow woman writer in Vixen}

If Braddon champions the prolific popular novelist as a "productive labourer" in The Doctor's Wife, she continues these self-reflexive interventions in contemporary debates about literature in her later novel, Vixen, with the additional dimension of a gendered perspective. Given her tendency to reflect within her fictions on the nature of authorship and her defence of sensationalism as a legitimate literary mode ${ }^{41}$, it is perhaps surprising that among Braddon's characters there are not more figures of the woman writer. ${ }^{42}$ Nonetheless, where such characters do appear, they offer interesting insights into Braddon's ambivalent negotiation of gendered constructions of the Victorian writer and of her own reputation. In Vixen, Braddon depicts two characters that express this ambivalence, with both embodying negative stereotypes about the high-brow "woman of letters".

Published in 1879, Vixen draws on elements of the earlier sensation novels, but remains in essence "a simple easy-going love story", as Braddon herself termed it. ${ }^{43}$ Violet Tempest and Roderick Vawdrey, known affectionately to each other as Vixen and Rorie, grow up on neighbouring properties in the Hampshire New Forest and seem destined to marry one another. Complications arise with the death of Vixen's adored father and her mother's subsequent remarriage to the fortune-hunter Conrad Winstanley, whom Vixen loathes. Rorie, misled into believing that Vixen is actually to marry Winstanley, becomes engaged to his cousin, Lady Mabel, in a filial gesture to please his dying mother. By the time he discovers the true state of affairs and realises his love for Vixen, Rorie is bound by honour to the engagement he now regrets. Yet Mabel's function in the novel is far more than simply that of providing an obstacle to true love's course. She is also a foil for the heroine, Vixen, and a vehicle for Braddon's extended satire on the aspiring female poet.

In stark contrast to Vixen, who is happiest in the stables or roaming around the countryside with her dogs, Mabel is a highly-cultured and refined young lady, who devotes her time to literature, music, politics, philosophy, languages, and the cultivation of orchids. Not everyone around her is sympathetic to Mabel's erudite pursuits; one character opines that

[Lady Mabel] is over-educated and conceited; sets up for a modern Lady Jane Grey, quotes Greek plays, I believe, and looks astounded if people don't understand her. She'll end by establishing a female college, like Tennyson's princess. ${ }^{44}$ 
Mabel's intellectual accomplishments are repeatedly commented on in ways designed to position the reader unsympathetically in relation to her. Whereas Braddon encourages her readers to identify with Vixen, a girl of average education for her class and gender and with no pretensions to intellectual prowess, Mabel invites the reader's mockery. Yet it is not Mabel's highbrow interests per se that Braddon satirises; it is the fact that, as the idolised only daughter of a Duke, Mabel has obtained an inflated idea of her own abilities. Rorie confides to Vixen that Mabel "reads Greek, and goes in for natural science, and has a good many queer ways [...] She has been brought up in an atmosphere of adulation, and that has made her a little self-opinionated" ${ }^{45}$ On the one hand, then, the object of Braddon's satire (just as in The Doctor's Wife) is the privileged dilettante, who plays at literature, as opposed to the professional who works at it. On the other hand, Mabel's characterisation is designed to highlight Vixen's "ordinariness", which makes her accessible to Braddon's imagined reader of popular fiction, who it is supposed will be similarly ignorant of Greek poetry and metaphysical arguments.

Braddon champions the popular (and implicitly herself) by encouraging the reader to identify with Vixen and Rorie, and by making Mabel's high-culture pretensions the object of satirical humour. However, Braddon also encourages the reader to question the validity of Vixen's self-confessed philistinism. Despite her passion for dogs and horses, Vixen does also read, although she appears to accept Mabel's opinion that her tastes are middle-brow at best: "I shall never try to become a highly cultivated young woman. I shall read Byron, and Tennyson, and Wordsworth, and Keats, and Bulwer, and Dickens, and Thackeray, and remain an ignoramus all the days of my life." poets and authors are the reading of an "ignoramus", particularly since they constitute a list of Braddon's own favourite writers. Moreover, the effect of listing so many names, where one or two would have been sufficient for the purpose, produces the adverse impression regarding Vixen's literary preferences, and also suggests Braddon's ironic interrogation of the boundaries between the high-brow and the popular. Vixen's favoured reading is linked in to a defence of the popular, which is familiar from Sigismund Smith's engaging disquisitions on literature in The Doctor's Wife. When Mabel catechises Vixen on the splendours of Chopin, the latter admits to preferring Mozart: “'Do you, really?' inquired Lady Mabel, looking as if Violet had sunk fathoms lower in her estimation by this avowal. 'Don't you think that he is dreadfully tuney?", to which Vixen responds that she likes "tunes". ${ }^{47}$ A similar conversation takes place later in the novel between Mabel and Rorie, which is worth quoting at some length since it exemplifies my point here. Lady Mabel is writing a long metaphysical poem entitled "The Tragedy of a Sceptic Soul", which the narrator disparages as "diluted Hegelism" and a "feeble imitation of Browning's obscurest verse". ${ }^{48}$ Rorie, whose literary tastes closely parallel those of Vixen, tries to advise his fiancée to make her work more accessible:

“...frankly, my dear Mabel, if you want your book to be popular--"

"I don't want my book to be popular .... If I had wanted to be popular, I should have worked on a lower level. I would even have stooped to write a novel."

"Well then I will say, if you want your poem to be understood by the average intellect, I really would sink the scientific terminology, and throw overboard a good deal of the metaphysics. Byron has not a scientific or technical phrase in all his poems." 
"My dear Roderick, you surely would not compare me to Byron, the poet of the Philistines $[\ldots]$ ".

"I beg your pardon, my dear Mabel. I'm afraid I must be an out and out Philistine, for to my mind Byron is the prince of poets. I would rather have written 'The Giaour' than anything that has ever been published since it appeared."

"My poor Roderick!" exclaimed Mabel, with a pitying sigh. "You might as well say you would be proud of having written 'The Pickwick Papers'."

"And so I should!" cried Rorie heartily. "I should think no end of myself ... one of the finest things that was ever written." 49

Here Braddon returns to the idea previously articulated by her character Sigismund Smith in The Doctor's Wife, who informs his friend, George Gilbert, that he "would rather be the author of Box and Cox [a popular farce], and hear my audience screaming with laughter ... than write a dull five-act tragedy, in the unities of which Aristotle himself could find no flaw" (47). ${ }^{50}$ Not only is Braddon implicitly questioning high-culture critical opinions that depreciate the work of popular writers such as Dickens, but she also expounds here a philosophy of writing that places the reader's pleasure at the centre of the process. Moreover, Braddon is clearly confident that her own readers will respond to Mabel's views as empty pretension and literary snobbery, since readers of the type of novel Braddon is writing are arguably likely to admire the fiction of Dickens also.

This emphasis on the pleasure of the reader and Braddon's implicit assertion that authors should write for their readers, is reinforced by the introduction of a second female writer late in the novel, when Vixen is sent to live on Jersey with an elderly spinster aunt of her stepfather. Miss Skipworth is a kind of female Casaubon, whose life's work has been the researching and writing of a scholarly tome expounding the creation of a universal religion. The narrator makes clear that this book upon which she has worked for decades will, like Casaubon's Key to all Mythologies, never be completed or published and, in this way, Miss Skipworth's failure to complete one book is the antithesis of Braddon's prolific production. Like Mabel, Miss Skipworth is held up to gentle ridicule - Vixen likens her "fanaticism" to "the hallucination of an old woman in Bedlam, who fancies herself Queen Victoria" (357) and the commonality between them lies in a shared delusion, both about their own abilities and the likely reception of their work. Miss Skipworth has made her "literary labours [...] the chief object of [her] existence" in a bid to achieve fame and glory for her family name. Similarly, Mabel seeks "her own small world of admirers, an esoteric few [...] holding themselves apart from the vulgar herd. ${ }^{, 51}$ Both characters scorn the popular and conform less to the emergent nineteenth-century figure of professional female authorship and more to the eighteenth-century notion of the "woman of letters" or "literary ladies", as defined by scholars such as Norma Clarke. ${ }^{52}$ The satirical treatment of their literary and intellectual aspirations in Vixen may appear to be evidence of anti-intellectualism and anti-feminism on Braddon's part, but I would suggest that it has more to do with her wider defence of popular forms of writing.

Mabel's poem fails to secure her the adulation of an intellectual elite, despite the best editorial efforts of Lord Mallow, an Irish peer who admires the fair "poetess". Purely in a bid to please her, Mallow offers to read "The Tragedy of a Sceptic Soul" and give an honest opinion of its merits. Mabel adjures him to be "as severe as an Edinburgh reviewer", to which his Lordship promises that he will "try to imagine [him]self an elderly feminine contributor to the Saturday, looking at you with vinegar gaze through a pair of spectacles, bent upon 
spotting every fleck and flaw in your work, and predetermined not to see anything good in it." ${ }^{, 53}$ This is an obvious swipe on Braddon's part at the brutal reviews she herself had received in the past from the Saturday Review, many of them doubtless from the pen of Eliza Lyn Linton, caricatured here, who attacked sensation fiction in her essay 'Little Women' in $1866 .{ }^{54}$ Mallow's comments also become a prophetic summary of Mabel's actual treatment at the hands of the critics, when her anonymous and tastefully-bound volume is judged "a dire and irredeemable failure" on publication. ${ }^{55}$ The humiliating death-blow to Mabel's literary aspirations is difficult to reconcile with the proto-feminist image of Braddon's work that has frequently been asserted. Mabel is never demonized in the novel, and she is granted a happy ending: having released Rorie from his engagement, she marries Lord Mallow and enjoys a successful career as a political wife. ${ }^{56}$ Her literary pretensions, however, are treated with merciless satire throughout, and it would be easy to interpret Braddon's representations of female writers as antifeminist and even hostile. Nonetheless, when considered collectively with representations of authorship elsewhere in her oeuvre, it becomes apparent that Braddon is concerned as much, if not more, with defending and endorsing popular modes of fiction than with issues of gender and writing. Ultimately, Lady Mabel is not punished for being a woman who desires to write, but for her conceited denigration of popular writing and readerships.

Beth Palmer has shown how Braddon, through various strategies, resisted, challenged, and reshaped the dominant negative connotations of sensationalism and popular authorship through her magazine Belgravia. ${ }^{57}$ As the discussions of The Doctor's Wife and Vixen in this article have demonstrated, this engagement with the nature of authorship extends into her novels too. Braddon's long career maps a changing model of literary composition and her interventions in contemporary debates through her fiction implicitly mount a defence against the attacks on her own prolific production. In this way, Braddon offers an important example of a bestselling female novelist, who both exemplified the changing construction of composition in the nineteenth century, but also engaged with and commented on this transition in interesting ways. Braddon's interventions reveal her conflict about the altered values and practices of the literary marketplace and her place within it, but also a sense of pragmatism. In a letter to Bulwer, she confessed that "the 'behind the scenes' of literature has in a manner demoralised me. I have learnt to look at everything in a mercantile sense, \& to write solely for the circulating reader". ${ }^{58}$ At the same time, though, she believed that a novelist should write with the pleasure of her readers in mind and this, perhaps, lies at the heart of her immense popularity and her status as a "queen of the circulating library".

\section{Notes}

${ }^{1}$ For further information on Braddon's extraordinary commercial success, see Robert Lee Wolff, Sensational Victorian: The Life and Fiction of Mary Elizabeth Braddon (London: Garland, 1979) and Jennifer Carnell, The Literary Lives of M. E. Braddon (Hastings: Sensation Press, 2000).

${ }^{2}$ Anxieties about the direction in which literary production was moving during this period are exemplified in the widespread debates over the sensation novel. Technological advances in paper production and printing methods, the abolition of the "taxes on knowledge" between 1853 and 1861, along with an ever-widening market for popular fiction, had facilitated an explosion in print culture by the mid-nineteenth century. Reviews and essays of the 1860s consistently express concerns about debased literary standards, which are perceived in large part to be a result of over-production and an emphasis on commercial profit over artistic 
merit. See eg. H. L. Mansel, [unsigned], "Sensation Novels", Quarterly Review 113 (Apr.1863): 483. For an excellent discussion of these issues, see Janice M. Allan, "The Contemporary Response to Sensation Fiction," The Cambridge Companion to Sensation Fiction, ed. Andrew Mangham (Cambridge: Cambridge UP, 2013) 85-98.

${ }^{3}$ Wolff, Sensational Victorian, 15.

${ }^{4}$ As Anthony Trollope famously stated, "We have become a novel-reading people [....] novels are in the hands of us all: from the Prime Minister down to the last-appointed scullery maid [...] Poetry also we read and history, biography, and the social and political news of the day. But all our other reading put together hardly amounts to what we read in novels". Trollope, "On English Prose Fiction as a Rational Amusement", in Four Lectures, ed. M. L. Parrish (London: Constable, 1938), 108.

${ }^{5}$ For example, Braddon conducted Belgravia, Mrs. Henry Wood edited The Argosy, Florence Marryat edited London Society, and Charlotte Riddell was the editor of the St. James's Magazine.

${ }^{6}$ For authoritative discussions on the democratization of the reading public and the expansion of the fiction market during this period, see Richard D. Altick, The English Common Reader: A Social History of the Mass Reading Public, 1800-1900 (University of Chicago Press, 1957); Graham Law, "The Professionalization of Authorship," The Oxford History of the Novel in English: Vol. 3 The Nineteenth-Century Novel 1820-1880, eds. John Kucich \& Jenny Bourne Taylor (Oxford: Oxford UP, 2011); Patrick Brantlinger, The Reading Lesson: The Threat of Mass Literacy in Nineteenth-Century British Fiction, (Indiana: Indiana University Press, 1998).

${ }^{7}$ [G. H. Lewes], "Criticism in Relation to Novels", Fortnightly Review 3 (Dec 1865): 352361 (353).

${ }^{8}$ Wolff, Sensational Victorian, 154.

${ }^{9}$ Robert Lee Wolff, “'Devoted Disciple': The Letters of Mary Elizabeth Braddon to Sir Edward Bulwer Lytton, 1862-1873”, Harvard Library Bulletin 12 (1974): 5-35 \& 129-161 (13).

${ }^{10}$ George Eliot, "Leaves from a Notebook", The Essays of George Eliot (Wildside Press, 2007), 236.

${ }^{11}$ Eliot, "Leaves from a Notebook" 236-7.

${ }^{12}$ The reviewers who criticised Braddon in these terms are too numerous to list here. Key examples include W. Fraser Rae, "Sensation Novelists: Miss Braddon", North British Review XLIII (Sept. 1865): 180-204, and Margaret Oliphant, "Novels", Blackwoods 102 (1867): 25780. In 1867 Braddon was publicly accused of plagiarising Octave Feuillet's Dalila in her novel Circe by the Pall Mall Gazette. Braddon had published this work under the pseudonym Babington White and the public identification of her authorship of Circe, after repeated denials, proved embarrassing. See Anne-Marie Beller, Mary Elizabeth Braddon: A Companion to the Mystery Fiction (Jefferson, NJ: McFarland, 2012) 50.

${ }^{13}$ Wolff, "“Devoted Disciple" (154).

${ }^{14}$ For an excellent recent discussion of these issues, see Linda H. Peterson, Becoming A Woman of Letters: Myths of Authorship and the Facts of the Victorian Marketplace (Princeton and Oxford: Princeton University Press, 2009).

${ }^{15}$ Peterson, Becoming A Woman of Letters, 2.

${ }^{16}$ Qtd. in Ken Gelder, Popular Fiction: The Logics and Practices of a Literary Field (Abingdon: Routledge, 2004) 15.

17 “Literature: Miss Braddon's New Novel”, Morning Post, 14 October 1865, 2.

18 "Recent Novels" (review of The Venetians), The Times, Wednesday 6 July 1892, 4

${ }^{19}$ Mansel, "Sensation Novels", 483. 
20 "Literature: Miss Braddon's New Novel”, Morning Post, 14 October 1865, 2.

${ }^{21}$ See Nicholas Daly, Literature, Technology and Modernity, 1860-2000 (Cambridge: Cambridge U P, 2004).

${ }^{22}$ Wolff, Sensational Victorian 134. Braddon, of course, was not the only novelist of the period to complain about the pressure of writing to deadlines. Neither was she alone in her extraordinary productivity. Contemporary female writers, such as Ellen Wood, Florence Marryat, and Margaret Oliphant were similarly, if not more, prolific. Oliphant also noted the pressure of producing sufficient work to support her dependents, and commented on "being told that I was working too fast, and producing too much". The Autobiography of Margaret Oliphant, ed. Elisabeth Jay (Peterborough, Ontario: Broadview, 2002) 104.

23 "One of Miss Braddon's", The Literary World 13 (Oct. 1882) 326.

24 "Topics of the Times", New York Times, 16 September 1897, 6.

${ }^{25}$ Richard Salmon, "'Farewell Poetry and Aerial Flights': The Function of the Author and Victorian Fiction," A Concise Companion to the Victorian Novel, ed. Francis O'Gorman (Oxford: Blackwell, 2005): 141.

${ }^{26}$ Margaret Oliphant, "Novels," Blackwood's Edinburgh Magazine 102 (Sept. 1867) 257-80 (260).

${ }^{27}$ Lyn Pykett, "Introduction", M. E. Braddon, The Doctor's Wife (Oxford: Oxford U P, 1998) ix; Wolff, Sensational Victorian 126.

${ }^{28}$ Mary Elizabeth Braddon, The Doctor's Wife. Ed. Lyn Pykett (Oxford: Oxford U P, 1998).

${ }^{29}$ Braddon, The Doctor's Wife 130.

${ }^{30}$ Braddon, The Doctor's Wife 136.

${ }^{31}$ Braddon, The Doctor's Wife 13.

${ }^{32}$ Braddon, The Doctor's Wife 8, 12.

${ }^{33}$ See page 2 above (note 7).

${ }^{34}$ Pykett, "Introduction" $\mathrm{x}$.

${ }^{35}$ Braddon, The Doctor's Wife 85.

${ }^{36}$ Braddon, The Doctor's Wife 229.

${ }^{37}$ Braddon, The Doctor's Wife 45.

${ }^{38}$ For example, in her first novel, a penny serial entitled Three Times Dead (1861), Braddon took quite literally the publisher's request that the work should "combine ... the human interest and genial humour of Dickens with the plot-weaving of G. W. Reynolds". Although not plagiarism in the sense that Smith seems to advocate, the styles of both Dickens and Reynolds are imitated to the point of pastiche at times in this novel. See M. E. Braddon, "My First Novel", Idler, 3 (1893): 19-30 (19). For details of the Pall Mall Gazette's accusations of Braddon as a plagiarist see note 11 above.

${ }^{39}$ See Jerome McGann, The Romantic Ideology: A Critical Investigation (Chicago \& London: University of Chicago Press, 1985).

${ }^{40}$ Mary E. Braddon, Vixen (Stroud: Alan Sutton Publishing, 1993) 386.

${ }^{41}$ For example, in the wake of extensive attacks on her work in the critical press, Braddon commissioned her friend George Augustus Sala to write essays in defence of sensation fiction, which were published, under her editorship, in the monthly periodical Belgravia. See "The Cant of Modern Criticism", Belgravia, IV (Nov. 1867): 45-55; "On the Sensational in Literature and Art", Belgravia IX (1868): 449-458.

${ }^{42}$ Among Braddon's extensive oeuvre, there are few examples of female characters who pursue writing as a career. In the late historical novel, The Infidel (1900), Antonia Thornton assists her father in his literary labours as a hack writer on Grub Street. Coralie Urquhart in Thou Art the Man (1894) has been seen as a figure for the Victorian woman writer, though her literary activities are confined to diary entries. See Laurence Talariach-Veilmas, 
"Introduction", Thou Art the Man (Kansas City: Valancourt, 2008). Stella Boldwood in One Thing Needful (1886) finds her vocation as a writer and publishes a high-brow novel to extensive critical acclaim. For an insightful discussion of this novel see Kate Mattacks, "Mary Elizabeth Braddon's Secret: An Antifeminist Amongst the New Women", in Tamara S. Wagner, ed., Antifeminism and the Victorian Novel: Rereading Nineteenth-Century Women Writers (Amherst, NY: Cambria Press, 2009).

${ }^{43}$ Wolff, Sensational Victorian 278.

${ }^{44}$ Braddon, Vixen 144.

${ }^{45}$ Braddon, Vixen 214.

${ }^{46}$ Braddon, Vixen 107.

${ }^{47}$ Braddon, Vixen 238.

${ }^{48}$ Braddon, Vixen 382.

${ }^{49}$ Braddon, Vixen 383.

${ }^{50}$ Braddon, The Doctor's Wife 47.

${ }^{51}$ Braddon, Vixen 354; 398.

${ }^{52}$ See Norma Clarke, The Rise and Fall of the Woman of Letters (London: Pimlico, 2004).

${ }^{53}$ Braddon, Vixen 387.

${ }^{54}$ Eliza Lynn Linton, “Little Women,” Saturday Review 25 (25 April 1868): 545-46. The

Saturday Review regularly reviewed Braddon's novels and also commented disparagingly on her prolific production: eg. 'Hardly have we sent back to the library the last wondrous product of Miss Braddon's imagination, before we find ourselves tempted once more with a fresh draught of surprise from the same inexhaustible spring.' [Unsigned], 'The Doctor's Wife', The Saturday review, 5 November 1864, p.571-2 (571).

${ }_{56}^{55}$ Braddon, Vixen 397.

${ }^{56}$ There is considerably more to be said about Braddon's treatment of Mabel and her ultimate subordination through marriage, but this aspect of the novel lies beyond the parameters of the present discussion.

${ }^{57}$ Beth Palmer, Women's Authorship and Editorship in Victorian Culture: Sensational Strategies (Oxford: Oxford University Press, 2011).

${ }^{58}$ Wolff, "Devoted Disciple" 14. 